\title{
Neurofibromatosis type 1 in Israel: survey of young adults
}

Ben Zion Garty, Arie Laor, Yehuda L Danon

\begin{abstract}
Neurofibromatosis type 1 (NF1) (von Recklinghausen's disease) is one of the most common human autosomal dominant disorders. In a survey of 37444017 year old Jewish recruits for military service, 390 cases of NF1 were discovered, with a prevalence of $1 \cdot 04 / 1000(0 \cdot 94 / 1000$ for males and $1 \cdot 19 / 1000$ for females), or two to five times the reported prevalence of this disease. NF1 was more common in youngsters whose parents were of North African and Asian origin $(1 \cdot 81 / 1000$ and $0 \cdot 95 / 1000$, respectively) and less common in those of European and North American origin $(0 \cdot 64 / 1000)$. All these differences were statistically significant and may be partially explained by the more advanced parental age of the NF group (as suggested by the larger number of children in the North African and Asian families) or by founder effect or both. The height and weight of the NF1 subjects was significantly lower than those of the controls. The intelligence score of persons with NF1 was similar to that of the control group when corrected for gender and ethnic origin. No significant increase in epilepsy or mental illnesses was found. This study provides evidence of the high overall prevalence of NF1 among Jews in Israel, with significantly increased prevalence in certain ethnic groups.
\end{abstract}

( $\mathcal{F}$ Med Genet 1994;31:853-857)

Department of Paediatrics, and the Kipper Paediatric Immunology and Allergy Unit, Allergy Unit, The Children's Israel, Beilinson Medical Campus, Petah Tiqva, Sackler School of Medicine, Tel Aviv University, Israel

B Z Garty

The Medical Corps, Israel Defence Forces, Israel

A Laor

Y L Danon

Correspondence to Dr Garty,

Department of

Paediatrics A

Children's Medical Centre of Israel,

Beilinson Medical Campus, Petah Tiqva 49202, Israel.

Received 15 February 1994 Revised version accepted for publication 25 May 1994
Neurofibromatosis type 1 (NF1), previously known as von Recklinghausen's disease, is one of the most common human genetic disorders. ${ }^{1-4}$ The disease is characterised by café au lait spots, neurofibromas of the skin, and iris hamartomas (Lisch nodules). The skeleton, endocrine glands, and central nervous system may also be involved. There is no known racial, ethnic, or geographical predilection for the condition. ${ }^{5}$ We conducted a study of the prevalence of NF1 among Israeli military recruits and investigated some of the clinical features of the affected persons. In contrast to most other surveys of NF1, ours did not use a clinic or hospital population; therefore, the selection of persons with more severe features of NF1 was avoided. ${ }^{36}$

\section{Material and methods}

The computerised data of 374440 consecutive military recruits (220215 males and 154225 females) were reviewed to investigate the pre- valence of NF1 in the Israeli Jewish population and to examine some of the clinical features (weight, height, and intelligence) of the affected persons.

The Israeli National Services Act requires that all citizens report to the induction centres of the Israel Defence Forces (IDF) at the age of 17 years for evaluation of fitness for military duty. Those exempted include Arabs (who are, therefore, not routinely examined), orthodox Jewish females (therefore more boys than girls are examined), and the severely physically disabled. The characteristics of the population seen at the induction centres, the examinations and studies performed, and the classification system are described in detail elsewhere. ${ }^{7}$

The diagnosis of NF1 was established by the IDF physicians at the induction centre. They also received medical information regarding the recruits from family physicians and paediatricians. In case of doubt, they were tested by experts in genetics or dermatology.

The criteria for the diagnosis of NF1 were slightly but not substantially different from those of the National Institute of Health consensus. Diagnosis was based on the presence of six or more café au lait spots over $1.5 \mathrm{~cm}$ each, accompanied by neurofibromas or axillary freckling. or a family history of neurofibromatosis. Ocular examination for iris hamartomas (Lisch nodules) was performed in only a few persons. This may have resulted in underdiagnosis of mild NF1 but not in overdiagnosis.

Intelligence was determined by a translated version of the verbal Otis test and a non-verbal test. The scores were then transformed into values that correlate with the Wechsler Adult Intelligence Scale (WAIS).

The control group of the study comprised all the recruits for military service who were not diagnosed as having NF1.

\section{STATISTICAL METHODS ${ }^{8-10}$ \\ Discrete variables}

For two way contingency tables, a $\chi^{2}$ test of homogeneity was used, and for $2 \times 2$ tables Fisher's exact test. Cochran-Mantel-Haenzel statistics and the corresponding confidence interval were used to determine the association between the prevalence of NF1 and other clinical features after adjusting for gender and ethnic group.

\section{Continuous variables}

Means and standard errors were calculated for each variable (height, weight, body mass index, 
Table 1 Prevalence of neurofibromatosis type 1 in Fewish military recruits in Israel

\begin{tabular}{llllll}
\hline & $N F 1$ & & \multicolumn{2}{l}{ Controls } \\
\cline { 2 - 3 } \cline { 5 - 6 } & No & $\%$ & & No & $\%$ \\
\hline Males & 206 & $52 \cdot 8$ & & 220009 & $58 \cdot 8$ \\
Females & 184 & $47 \cdot 2$ & & 154041 & $41 \cdot 2$ \\
Total & 390 & 100 & & 374050 & 100 \\
\hline
\end{tabular}

The difference in prevalence between males and females is significant $(p<0.05$, Fisher's exact test).

Table 2 Prevalence of neurofibromatosis type 1 in fewish military recruits according to ethnic groups

\begin{tabular}{lcrl}
\hline Origin* $^{*}$ & $\begin{array}{l}\text { No of NF1 } \\
\text { patients }\end{array}$ & $\begin{array}{l}\text { No of } \\
\text { controls }\end{array}$ & $\begin{array}{l}\text { Prevalence } \\
(\%) 0\end{array}$ \\
\hline Israel & 8 & 24800 & 0.32 \\
North Africa & 185 & 102131 & 1.81 \\
Asia & 99 & 104633 & 0.95 \\
South America & 9 & 6362 & 1.41 \\
Europe \& & & 135135 & 0.64 \\
$\quad$ North America & 87 & 374050 & 1.04 \\
Total & 390 &
\end{tabular}

*Origin refers to the place of birth of the parents, "Israel" means that the father and grandfather were born in Israel; "North Africa", mainly Sephardic Jews; "Asia", mainly Jews of Middle East countries; "South America", Sephardic and Ashkenazic Jews, "Europe \& North America", mainly Ashkenazic Jews.

Data on ethnic group was unavailable for two NF1 patients and 2914 controls.

IQ, etc). Three way analysis of variance (ANOVA) models of gender, ethnic group, and presence of NF1 were used for comparisons between affected persons and controls. Incremental sums of the square of each independent variable were added, so that the significance results for the effect of NF1 would not be biased by gender or ethnic group.

The identity of several distribution functions was tested by the two sided Smirnov test.

All computations were performed using SAS software. ${ }^{11}$

\section{Results}

Of the 374440 Israeli military recruits, 390 had NF1 (table 1). For fitness evaluation purposes, the disease was classified as mild (no functional disturbances) (372 persons), moderate (localised functional disturbances, mainly orthopaedic disabilities such as pseudarthrosis) (15 persons), and severe (space occupying lesions in internal organs or brain) (three persons). Only those with moderate or severe NF1 were given a lower fitness ranking.

The prevalence of NF1 in the population studied was 1.04 per 1000 . When analysed according to gender, it was 0.94 per 1000 males and 1.19 per 1000 females. This difference was statistically significant $(p<0.05$, Fisher's exact test). When analysed according to ethnic origin (table 2), the disease proved to be more common among Jews of North African or Asian origin ( $1.81 / 1000$ and $0.95 / 1000$, respectively) and less common among Jews of European or North American origin $(0 \cdot 64 / 1000)$. The differences were highly significant $(\mathrm{p}<0.0001$, $\chi^{2}$ test).

The prevalence of NF1 among recruits from families living in Israel for at least three generations (that is, father and grandfather born in Israel) was even lower (0.32 per 1000); however, because of the relatively small number of persons in this subgroup, this result should be considered with caution.

Mean height and weight of persons with NF1 was significantly lower than those of the control group (table 3). Body mass index $\left(\mathrm{kg} / \mathrm{m}^{2}\right)$, although lower in persons with NF1, was not significantly different in comparison to the controls. The intelligence of the NF1 persons was lower when compared to the controls, but similar when corrected for gender and ethnic origin (table 3). There were no significant differences in the prevalence of seizure disorders (epilepsy) or major mental illnesses in the two groups, although seizure disorders were slightly more common and major mental illness slightly less common in persons with NF1 (table 4).

\section{Discussion}

NF1 is one of the most frequent, potentially serious, human genetic disorders. It is inherited as an autosomal dominant condition with almost $100 \%$ penetrance, and its mutation rate is so high $\left(1 \times 10^{-4}\right.$ mutations/gamete/generation, ${ }^{3} 100$ fold higher than the average mutation rate at a single locus) that half the newly diagnosed subjects are considered to represent a new mutation. ${ }^{23}$ Both sexes are affected with equal frequency and severity, ${ }^{2}$ although some studies showed an apparently worse prognosis in females. ${ }^{3512}$

The gene for NF1 has been recently located in the pericentromeric region of the long arm of chromosome $17,,^{13}$ and there are several DNA markers that can be used for prenatal diagnosis by linkage analysis, with an accuracy of $>95 \% .^{14}$

In 1987 the Consensus Panel of the National Institutes of Health established the definition of neurofibromatosis. ${ }^{15}$ Although diagnosis of NF1 is usually straightforward, problems may arise when assessing young children in whom multiple café au lait spots are the only presenting feature, and the parents are unaffected. ${ }^{3}$ The clinical features of NF1 become more

Table 3 Comparison between neurofibromatosis type 1 and control group regarding height, weight, body mass index, and $I Q$

\begin{tabular}{|c|c|c|c|c|c|c|c|c|c|c|}
\hline & \multicolumn{5}{|l|}{ Males } & \multicolumn{5}{|c|}{ Females } \\
\hline & $\begin{array}{l}\text { NF1 } \\
\text { Mean }\end{array}$ & $(S E)$ & $\begin{array}{l}\text { Controls } \\
\text { Mean }\end{array}$ & $(S E)$ & Significance & $\begin{array}{l}\text { NF1 } \\
\text { Mean }\end{array}$ & $(S E)$ & $\begin{array}{l}\text { Controls } \\
\text { Mean }\end{array}$ & $(S E)$ & Significance \\
\hline $\begin{array}{l}\text { Height }(\mathrm{cm}) \\
\text { Weight }(\mathrm{kg}) \\
\text { Body mass index }\end{array}$ & $\begin{array}{r}172 \cdot 3 \\
61 \cdot 8\end{array}$ & $\begin{array}{l}(0 \cdot 5) \\
(0 \cdot 7)\end{array}$ & $\begin{array}{r}173 \cdot 5 \\
63.7\end{array}$ & $\begin{array}{l}(0.01) \\
(0.02)\end{array}$ & $\begin{array}{l}\mathrm{p}<0.01^{*} \\
\mathrm{p}<0.01^{*}\end{array}$ & $\begin{array}{r}160 \cdot 5 \\
54 \cdot 7\end{array}$ & $\begin{array}{l}(0 \cdot 4) \\
(0 \cdot 6)\end{array}$ & $\begin{array}{r}162 \cdot 3 \\
56 \cdot 5\end{array}$ & $\begin{array}{l}(0 \cdot 02) \\
(0 \cdot 02)\end{array}$ & $\begin{array}{l}\mathrm{p}<0.01^{*} \\
\mathrm{p}<0.01^{*}\end{array}$ \\
\hline $\begin{array}{l}\left(\mathrm{kg} / \mathrm{m}^{2}\right) \\
\mathrm{IQ}\end{array}$ & $\begin{array}{l}20 \cdot 8 \\
99 \cdot 9\end{array}$ & $\begin{array}{l}(0 \cdot 2) \\
(1 \cdot 32)\end{array}$ & $\begin{array}{r}21 \cdot 1 \\
102 \cdot 9\end{array}$ & $\begin{array}{l}(0.006) \\
(0.04)\end{array}$ & $\begin{array}{l}\text { NS } \\
\text { NSt }\end{array}$ & $\begin{array}{r}21 \cdot 2 \\
107 \cdot 6\end{array}$ & $\begin{array}{l}(0 \cdot 2) \\
(1 \cdot 2)\end{array}$ & $\begin{array}{r}21 \cdot 4 \\
109 \cdot 6\end{array}$ & $\begin{array}{l}(0.008) \\
(0.04)\end{array}$ & $\begin{array}{l}\text { NS } \\
\text { NSt }\end{array}$ \\
\hline
\end{tabular}

NS $=$ not significant. ${ }^{*} \mathrm{p}<0.01$ after correction for ethnic group and gender (three way analysis of variance). + Not significant when adjusted for ethnic group and gender. 
Table 4 Comparison between NF1 patients and control group regarding some clinical features

\begin{tabular}{|c|c|c|c|c|c|}
\hline & \multicolumn{2}{|l|}{ Males } & \multicolumn{2}{|l|}{ Females } & \multirow{2}{*}{$\begin{array}{l}\text { Sex and ethnic origin } \\
\text { adjusted odds ratios } \\
(95 \% \text { confidence } \\
\text { intervals })^{*}\end{array}$} \\
\hline & NF1 (\%) & $\begin{array}{l}\text { Controls } \\
(\%)\end{array}$ & NF1 (\%) & $\begin{array}{l}\text { Controls } \\
\text { (\%) }\end{array}$ & \\
\hline $\begin{array}{l}\text { Seizure } \\
\text { disorders } \\
\text { Mental illness }\end{array}$ & $\begin{array}{l}4.9 \\
4.9\end{array}$ & $\begin{array}{l}3 \cdot 3 \\
6 \cdot 2\end{array}$ & $\begin{array}{l}5 \cdot 4 \\
5 \cdot 4\end{array}$ & $\begin{array}{l}2 \cdot 9 \\
7 \cdot 6\end{array}$ & $\begin{array}{l}\text { NSt } \\
\text { NSt }\end{array}$ \\
\hline
\end{tabular}

*Cochran-Mantel-Haenzel estimate based confidence interval.

†Not significant when adjusted for gender and ethnic origin.

pronounced with age, and the café au lait spots and neurofibromas increase in number and dimension. ${ }^{16}$ Most affected subjects can be diagnosed before the age of 5 years. ${ }^{17}$ The reported prevalence of NF1 varies. A USSR study of 16 year olds who underwent premilitary examination showed a very low prevalence of $1 /$ $7800,{ }^{18}$ suggesting possible underestimation. Prevalence was $1 / 4600$ in a Swedish study ${ }^{19}$ and $1 / 4950$ in a survey conducted in south east Wales. ${ }^{1720}$ Calculated "correction" for possible missed cases (new mutations without severe complications) increased the prevalence of NF1 in Wales to $1 / 4150 .{ }^{1720}$ Other authors, however, estimated a higher prevalence, in the range of $1 / 2500$ to $1 / 3500$ births. $^{2122}$ The highest reported prevalence was in Dunedin, New Zealand at $1 / 2190 .{ }^{23}$

The prevalence of NF1 in our study (1.04 per 1000) was two to five times higher than in these reports and estimations. This figure does not include some persons with severe complications, such as malignant tumours, who had either died of this disease at an earlier age or did not present themselves at the induction centres. However, the latter factor accounts for, at most, $5 \%$ of the total number of persons with NF1. 10

The high prevalence of NF1 in our study must also raise the possibility of overdiagnosis of the disease or inclusion of other entities similar to NF1 in our survey. Although the latter have been reported, ${ }^{2425}$ they are so rare that it is unlikely that their inclusion would have significantly altered the findings. The possible inclusion of persons with multiple café au lait spots, without other features of NF1, or the so called neurofibromatosis type 6, according to the classification of Riccardi (café au lait "only"), is also negligible, since the presence of six or more café au lait spots in itself indicates a greater than $99 \%$ likelihood of NF1. ${ }^{25}$ Furthermore, the diagnosis of NF1 was based on additional clinical findings, or family history or both.

Also of interest is the difference in prevalence by gender $(0 \cdot 94 / 1000$ for males versus $1 \cdot 19 /$ 1000 for females). We do not have a good explanation for this finding and it was only weakly significant. A slight preponderance of male NF1 patients has been reported by other authors. ${ }^{17}$ The natural history of males and females with NF1 is slightly different. ${ }^{523} \mathrm{~A}$ Danish study found reduced survival and increased risk of cancer in female patients with NF1; however, these were mainly manifested after the age of 17 years. ${ }^{23}$

The higher prevalence of NF1 in youngsters of North African and Asian origin (mainly
Sephardic Jews) relative to those of European or North American origin (mainly Ashkenazic Jews) is also surprising. There is no known racial, ethnic, or geographical predilection for NF1; however, only few epidemiological data are available from sources other than the United States and western Europe. ${ }^{5}$

There are some indications in medical publications that birth order or paternal age or both are related to the occurrence of de novo mutations in NF1..$^{23181926}$ These findings were not supported, however, by the studies of Huson et $a l^{2027}$ in south east Wales, Samuelsson and Axelsson ${ }^{19}$ in Sweden, or Rodenhiser et $a l^{16}$ in south western Ontario. Sergeyev, ${ }^{18}$ who pooled the data from his own and three previous studies, showed that NF1 subjects were born later than normal sibs, and there was slightly advanced paternal, but not maternal, age. A study by Riccardi et al, ${ }^{26}$ although criticised because of a possibly biased sample, showed paternal and also mild maternal advanced age in patients with NF1. Thus, a partial explanation for the high prevalence of NF1 in certain ethnic groups, as in our study, may be the relatively large number of families with advanced parental age.

Our findings are supported by those of LevinStern $^{28}$ as reported in her MSc degree thesis at Tel Aviv University. She performed a genetic and clinical survey of 148 families from central Israel who fulfilled the NIH criteria for NF1 and found that only $25 \%$ of the families were of Ashkenazic origin, whereas the Ashkenazic population of central Israel at that time was $47 \%$. The remaining families $(75 \%)$ were of Middle Eastern and Sephardic origin (53\% of the general population). The latter group corresponds to the recruits of North African and Asian origin in our study. Levin-Stern ${ }^{28}$ concluded that the NF1 gene is more frequent in non-Ashkenazic Jews. In addition, 70 sporadic subjects with NF1 (out of the 148 probands in her study) were considered to represent a new mutation; of these, $29 \%$ were Ashkenazic Jews and $71 \%$ Sephardic Jews. The mean paternal age of the new mutation group was significantly higher $(36.5$ years) than that of the familial NF1 group (27.3 years) or of the general population $(29 \cdot 3 \text { years })^{28}$

Since direct information on parental age and birth order was not available in the present study, we analysed the number of children in the families of 240000 consecutive military recruits, assuming that the likelihood of higher parental age correlates with a larger number of children in the family. The results (table 5)

Table 5 Distribution of number of children in families of different ethnic groups in Israel

\begin{tabular}{llllll}
\hline Origin & \multicolumn{7}{l}{ Selected quantiles } \\
\cline { 2 - 6 } & 10 & 25 & 50 & 75 & 90 \\
\hline North Africa & 3 & 4 & 5 & 7 & 10 \\
Asia & 3 & 3 & 4 & 6 & 8 \\
Europe \& North & 2 & 2 & 3 & 4 & 5 \\
America & 2 &
\end{tabular}

The computations were based on the data of 240000 consecutive recruits.

The distributive functions of the number of children in families of different ethnic groups are not identical. ( $<<0.001$, two sided Smirnov test.) 
showed a larger number of children in families of North African and Asian origin, with a 90th quantile of 10 and eight children, respectively, compared to European and North American families with a 90th quantile of five children. Although these data are not direct evidence of the influence of increased parental age on the rate of NF1 mutation, it is a possibility and should be tested in larger population studies. However, even it were correct, it is difficult to assume that this factor may by itself explain the very high prevalence of NF1 in the Jewish population of Israel.

A second possible explanation for the high prevalence of NF1 in our study is a founder effect which may cause a high prevalence of genetic disorders in relatively small populations. The high prevalence of NF1 in the Dunedin region of New Zealand (52 affected subjects out of a population of 113700) was also attributed to a possible founder effect. The founder effect may also explain the difference in prevalence of NF1 in different ethnic Jewish groups found in our study. Founder effect has also been proposed to explain the high prevalence of Tay-Sachs disease in Ashkenazi Jews and glycogen storage disease type III and ataxia telangiectasia in Moroccan Jews. ${ }^{29}$

Another possible contributory factor to the high prevalence of NF1 in certain populations may be a higher rate of diagnosis of the disease in patients with darker skin (which makes the café au lait spots more easily observable). ${ }^{21}$ However, it is unlikely that this would even partially explain the great differences in prevalence among the ethnic groups found in our survey.

Our study showed significantly shorter stature in both males and females with NF1 confirming the recent suggestion of impaired growth in the disease. In the survey done in Wales, $34 \%$ of persons with NF1 were on or below the 3 rd centile for height. ${ }^{20}$ In another study, the median height of 137 patients was on the 25 th centile and the mean on the 34th; in $16 \%$, height was on or below the 3 rd centile. ${ }^{2}$ The weight of NF1 persons in our study was also significantly lower in comparison to the controls. However, the body mass index $\left(\mathrm{kg} / \mathrm{m}^{2}\right)$ of the NF1 group was similar to that of the controls.

Neurological manifestations of NF1 include neoplasms of the central nervous system, seizures, mental retardation, attention deficit, and behavioural disorders. ${ }^{30-32}$ Although up to $40 \%$ of children with NF1 were reported to have some intellectual handicap, moderate to severe mental retardation is found in only a small proportion (perhaps 2 to $5 \%$ ), and the vast majority have only learning difficulties. ${ }^{2732}$ In a study comparing 13 pairs of sibs aged 6 to 27 years, one affected with NF1 and the other unaffected, no preponderance of mental retardation, attention deficit disorder, or specific learning disorders was found in the NF1 group; however, the NF1 group had lower full scale IQ scores (94 $v 105)$ and a visual-spatial orientation deficit. ${ }^{1}$ Our study showed that persons with NF1 have, as a group, a lower IQ when compared to controls, but this difference becomes insignificant after correction for gender and ethnic origin.

Although several reports have suggested a high prevalence of seizure disorders in NF1 ${ }^{2021}$ this was not confirmed in our survey; although seizure disorders were slightly more frequent, the difference did not reach significance.

The major limitation of our study was that NF1 patients with malignancy or debilitating states may not have reached the induction centres and therefore may have been missed. The advantage of our survey of military recruits is that the bias towards more complicated cases seen in specific clinic or hospital studies is eliminated. ${ }^{2333}$ Another advantage of our survey is that by the age of 17 years, most persons with NF1 will have developed sufficient signs for diagnosis.

The present study provides evidence for the high prevalence of NF1 among Jews in Israel, with significantly increased prevalence in certain ethnic groups.

This work was supported in part by the Doron Foundation.

1 Eldridge R, Denkla MR, Bien E, et al. Neurofibromatosis type 1 (Recklinghausen's disease). Neurologic and congestive assessment with sibling controls. Am f Dis Child 1989;143:833-7.

2 Riccardi VM Von Recklinghausen neurofibromatosis. $N$ Engl f Med 1981;305:1617-27.

3 Carey JC, Baty BJ, Johnson JP, Morrison T, Skolnick M Kivlin J. The genetic aspects of neurofibromatosis. Ann NY Acad Sci 1986;486:45-56.

4 Riccardi VM. Neurofibromatosis: past, present and future. $N$ Engl f Med 1991;324:1283-5

5 Sorensen SA, Mulvihill JJ, Nielsen A. On the natural history of von Recklinghausen neurofibromatosis. Ann NY Acad Sci 1986;486:30-7.

6 Tugwell PX. How to read clinical journals: to learn the clinical course in prognosis of disease. Can Med Assoc 7 1981;124:869-72.

7 Kark JD, Kedem R, Revach M. Medical examination of Israeli 17-years-olds before military service as a national resource for health information. Isr $\mathcal{F}$ Med Sci 1986;22: 318-25.

8 Kleinbaum DG, Kupper LL, Morgenstern H. Epidemiologic research: principles and quantitative methods. Belmont, $\mathrm{Ca}$ research: principles and quantic
lifornia: Wadsworth, 1982 .

9 Draper NR, Smith H. Applied regression analysis. 2nd ed. New York: John Wiley, 1981.

10 Conover WJ. Practical nonparametric statistics. 2nd ed. New York: John Wiley, 1980 .

11 SAS User Guide. Version 5. Cary, MC, SAS Institute Inc, 1985.

12 Carey JC, Laub JM, Hall BD. Penetrance and variability in neurofibromatosis; a genetic study of 60 families. Birth Defects 1979;15:271-81.

13 Baker D, Wright E, Nguyen K, et al. Gene for von Recklinghausen neurofibromatosis is in the pericentromeric region of chromosome 17. Science 1987;236:1100-2.

14 Goldgar DE, Green P, Parry DM, Mulvihill JJ. Multipoin linkage analysis in neurofibromatosis type 1: an in-

5 National Institutes of Health. Consensus Development Conference: neurofibromatosis. Arch Neurol 1988;45:575-8.

16 Rodenhiser DI, Coulter-Mackie MB, Jung JH, Singh SM A genetic study of neurofibromatosis in south-western Ontario. I Population, familial segregation of phenotype, and molecular linkage. $\mathcal{7}$ Med Genet 1991;28:746-51.

17 Huson SM, Compston DAS, Clark P, Harper PS. A genetic study of von Recklinghausen neurofibromatosis in southeast Wales. I Prevalence, fitness, mutation rate, and effect of parental transmission on severity. 7 Med Genet 1989 ; 26:704-11.

18 Sergeyev AS. On the mutation rate of neurofibromatosis. Humangenetik 1975;28:129-38.

19 Samuelsson B, Axelsson R. Neurofibromatosis. A clinical, and genetic study of 96 cases in Gothenburg, Sweden Acta Dermatol Venerol Suppl (Stockh) 1981;95:67-71.

20 Huson SM, Harper PS, Compston DAS. Von Recklinghausen neurofibromatosis: a clinical and population study in south east Wales. Brain 1988;111:1355-81.

21 Fienman NL, Yakovac WC. Neurofibromatosis in childhood. F Pediatr 1970;76:339-46.

22 Sorensen SA, Mulvihill JJ, Nielsen A. Long-term follow up of von Recklinghausen's neurofibromatosis. $N$ Engl $\mathcal{F} \mathrm{Med}$ 1986;314:1010-5.

23 Fuller LC, Cox B, Gardner RJM. Prevalence of von Recklinghausen neurofibromatosis in Dunedin, New Zealand. Neurofibromatosis 1989;2:278-83.

24 Lycka B, Krywonis N, Hordinsky M. Abnormal nevoblast 
migration mimicking neurofibromatosis. Arch Dermatol 1991;127:1702-4.

25 Riccardi VM. Neurofibromatosis mimicry. Arch Dermatol 1991;127:1714-5.

26 Riccardi VM, Dobson CE, Chakraborty R, Bontke C. The pathophysiology of neurofibromatosis. IX. Paternal age as a factor in the origin of new mutations. Am $\mathcal{F}$ Med Genet 1984;18:169-76.

27 Huson SM, Compston DAS, Harper PS. A genetic study of von Recklinghausen neurofibromatosis in south-east Wales. II Guidelines for genetic counselling. I Med Genet 1989;26:712-21.

28 Levin-Stern G. A genetic and clinical survey of neuro- fibromatosis in central Israel. MSc thesis, Tel Aviv University, 1988 .

29 Goodman RM. Genetic disonders among the fewish people. Baltimore: The Johns Hopkins University Press, 1979: 458-70.

30 Dunn DW. Neurofibromatosis in childhood. Curr Probl Pediatr 1987;17:451-97.

31 Eliason MJ. Neurofibromatosis: implications for learning and behaviour. F Dev Behav Pediatr 1986;7:175-9.

32 Rubenstein AE. Neurofibromatosis. A review of the clinical problem. Ann NY Acad Sci 1986;486:1-13.

33 Crawford AH. Neurofibromatosis in children. Acta Orhop Scand Suppl 1986;218:1-60. 